Orbis Tertius, vol. XXII, n ${ }^{\circ}$ 25, e040, junio 2017. ISSN 1851-7811

Universidad Nacional de La Plata

Facultad de Humanidades y Ciencias de la Educación

Centro de Estudios de Teoría y Crítica Literaria

\title{
Joaquín Zuleta Carrandi (Estudio y edición), Pedro Sarmiento de Gamboa. Sumaria Relación.
}

\author{
Madrid-Frankfurt, Iberoamericana-Vervuert, 2015, Biblioteca Indiana, 336
} páginas.

\section{Valeria Añón}

Preguntas y disputas en torno al archivo literario latinoamericano han estado en el centro de los debates en las últimas décadas. Su configuración, su materialidad, sus textos fundantes han sido objeto de polémicas y de intervenciones críticas de diversa índole. En este marco, los orígenes del archivo, renovados por la articulación entre picaresca, discurso legal y narrativa que propuso Roberto González Echevarría en su señero Mito y archivo. Una teoría de la narrativa latinoamericana ([1990] 2000), han recibido atención de aproximaciones críticas diacrónicas en torno a los problemas del corpus, el canon y la configuración de la literatura latinoamericana. De allí que esta vuelta crítica exigiera un nuevo recorrido por orígenes y bordes de esa amplísima categoría conocida por el genérico “crónicas de Indias”.

Desde la década de 1980 — celebraciones/remembranzas del Quinto Centenario del "Descubrimiento" de América de por medio-, han visto la luz numerosas colecciones y ediciones que reeditaban y ajustaban textos canónicos, o volvían a visitar otros, mal editados u olvidados, vinculados tanto con los bordes del imperio español como con los bordes (materiales y metafóricos) de ese archivo que vuelve posible la literatura contemporánea. El trabajo fue (es) ingente, y aún queda mucho por hacer en la medida en que buena parte de esta documentación se encuentra expoliada, perdida, repartida en bibliotecas europeas o norteamericanas; en cualquier caso, lejana o sesgada para el estudioso y el lego.

La edición de la Sumaria relación de Pedro Sarmiento de Gamboa que propone Joaquín Zuleta Carrandi (Universidad de Los Andes, Chile) se gesta en ese marco y se postula como intervención en dichas polémicas. Licenciado por la Universidad de Chile y Doctor por la Universidad de Navarra, España, Zuleta

Cita sugerida: Añón, V. (2017). [Revisión del libro Pedro Sarmiento de Gamboa. Sumaria Relación de Joaquín Zuleta Carrandi]. Orbis Tertius, 22(25), e040. https://doi.org/10.24215/18517811e040 
Carrandi escenifica en su propio derrotero los puntos de encuentro entre academias y concepciones acerca de la edición, el trabajo con el manuscrito y la intervención del crítico-editor. En este sentido, su labor constituye un ejemplo y una apuesta, que tiene continuidad tanto en su rol como secretario de la colección Letras del Reino de Chile (Editorial Universitaria-Universidad de Los Andes, Chile) como en su edición de las cartas inéditas de Pedro Sarmiento de Gamboa, en preparación. Para esta intervención crítica y política (no otra cosa es restablecer el archivo americano) Zuleta Carrandi selecciona un personaje paradigmático y único a un tiempo, Pedro Sarmiento de Gamboa (Pontevedra, 1530?/1592), y uno de sus textos más interesantes y menos editados de manera autónoma (hasta ahora): la Sumaria relación. Como personaje histórico, Sarmiento de Gamboa reúne varios roles posibles en la época: explorador, cosmógrafo, geógrafo, historiador, conquistador, nigromante incluso. Su biografía, que el editor puntúa con sintética erudición, incluye desde un temprano encontronazo con la Inquisición, acusado de haber llevado a cabo numerosas actividades clandestinas tales como "lectura de líneas de las manos, tintas mágicas, algunas palabras críticas hacia la Iglesia y más anillos capaces de otorgar poderes a su portador” (p. 19), hasta su labor como historiador y soldado a las órdenes del virrey Francisco de Toledo, famoso personaje en la vida política del Virreinato del Perú, quien impulsó, entre otras transformaciones, una inflexión historiográfica notable.

En este marco de tensiones, exploraciones y conquistas (Sarmiento de Gamboa participa en el “descubrimiento” de las islas Salomón en 1568, durante el gobierno del licenciado Lope García de Castro, del cual hace una primera relación), este cronista configura y despliega su labor historiográfica, que incluye también la Historia Índica, ambicioso proyecto en tres tomos (una historia natural, una historia de los incas y sus antepasados, una historia de la conquista del Perú), del cual sólo lleva a cabo el segundo, que es enviado al rey Felipe II en 1572, con la anuencia de los “42 descendientes de los 12 reyes incas” frente a quienes "hizo leer su obra, usando un intérprete, para obtener su aprobación como historia verdadera” (p. 25). Entre el testimonio, la historiografía y la configuración de nuevos espacios para el decir, la obra de Sarmiento de Gamboa se va perfilando en toda su complejidad y constituye así un sustrato fundamental para la posterior escritura de diversas relaciones que darán cuenta de otros derroteros, esta vez hacia las fronteras del imperio: el estrecho de Magallanes. Actor y sujeto de los cambios político-sociales del reinado de Felipe II, que el editor describe con acertado detalle, Sarmiento de Gamboa participará de nuevas expediciones en virtud de su doble condición de letrado (cosmógrafo, geógrafo, historiador) y soldado. Lo favorece el vínculo estrecho con el virrey Toledo, para quien se ha convertido en hombre de confianza; lo atraviesan las circunstancias inigualables de configuración del moderno Imperio español, a partir de la unión de las coronas de Castilla y Portugal (1580-1640). Esta excepcional situación afecta de manera central la política indiana de Felipe II, quien tiene entre sus manos los mayores territorios de los que un monarca gozara en "la historia de la humanidad” (p. 29), los cuales deben ser gobernados y defendidos contra numerosos ataques, en particular a manos de los corsarios británicos, entre los que se destaca Francis Drake (a cuyas andanzas en estas costas el editor también dedica espacio). En este marco se organizará una serie de expediciones al Estrecho de Magallanes, en las que Sarmiento de Gamboa tendrá rol protagónico como expedicionario, gobernador del Estrecho de Magallanes, testigo y narrador.

La primera expedición partió del Callao en 1579 y tenía "un carácter descubridor en el sentido de que pretende registrar la geografía austral, esto es, los accesos al Estrecho de Magallanes en la intrincada red de canales de la zona sur de Chile” (p. 46); fue inscripta en diversas relaciones y memoriales, algunos de ellos editados por primera vez en el siglo XVIII; otros, identificados en el Archivo General de Indias, como señala el editor en sus profusas notas. Un segundo momento tuvo lugar poco después y fue resultado del desarrollo de un proyecto defensivo de las fronteras del imperio por parte de la Corona, lo cual implicaba, además de fortificaciones variadas, la organización de una armada, "una empresa sin precedentes” (p. 52) cuya función era ostensiva y disuasoria a un tiempo ya que utilizó "todos los recursos existentes para asestar un golpe 
definitivo al corso y hacer una demostración de poder real ante los reinos enemigos” (p. 56). Luego de numerosas vicisitudes, la Armada del Estrecho "zarpa de Cabo Verde el 9 de diciembre de 1581” (p. 65). Todo ello, con sus prolegómenos, problemas e intrigas, ya que se trató de una expedición fracasada, fue referido en la Sumaria relación, redactada en España entre junio y septiembre de 1590, que constituye el objeto de esta edición.

Si bien hubo ediciones e impresiones previas, entre las que se destacan la de Luis Torres de Mendoza (1866), que se basa en la copia que Juan Bautista Muñoz encarga en 1782, y la de Ángel Rosenblatt de 1950 (también editor de la Historia de los incas en 1942), este volumen constituye una novedad y un acontecimiento. En primer lugar porque consigue darle unicidad y entidad propia a esta relación, en diálogo pero separada de los otros documentos de Sarmiento de Gamboa. Esta decisión editorial es el primero de muchos aciertos respecto del tratamiento del texto, que normaliza ortografía y acentuación sin perder las marcas diferenciales de una escritura y una lengua. Así, se consigue una relación amable para el lego, al tiempo que rigurosa para el especialista. A ello se suman los paratextos, que merecen una mención aparte. Me refiero aquí al estudio introductorio y documental, a las notas y a los anexos, verdaderos aportes para comprender las crónicas de Indias en general. El primero, que ofrece una introducción histórica y un estudio textual, lleva de la mano al lector, con elegancia y erudición, por los vericuetos del imperio español y las inflexiones de su archivo. El editor consigue poner orden en la maraña historiográfica acerca de temas tan extensos como la conformación del imperio español, las alianzas de Carlos V y Felipe II con otras coronas europeas, las vicisitudes del Virreinato del Perú a partir de la segunda mitad del siglo XVI y las expediciones sucesivas al Estrecho de Magallanes, articuladas como respuesta a los ataques de los corsarios británicos. Todo ello aparece en su justa medida, por medio de una elegante escritura que contextualiza los textos de Sarmiento de Gamboa y los coloca en una serie que, de ese modo, exhibe la complejidad y textura del archivo americano.

Mención especial exige el estudio textual, hallazgo principal puesto que detalla las decisiones editoriales y anticipa hipótesis respecto de autorías y derroteros de los manuscritos. Allí, Zuleta Carrandi se sumerge en un problema central: el de la circulación, lectura y escritura de estos textos en el siglo XVI, y sus copias, usos y expoliaciones en siglos posteriores. Interesan en especial las especificaciones respecto de tachaduras, enmiendas, agregados y notas al margen, ingente trabajo que exige cotejos de manuscritos y ediciones, saberes paleográficos expertos, atención al detalle. Claro que no se trata de la obsesión de un editor: estos recorridos detectivescos llevan a formular hipótesis acerca de las anotaciones marginales y del "primer lector” de esta relación que, como Zuleta Carrandi demuestra, fue el licenciado Gasca de Salazar, oidor del Consejo de Indias con quien Sarmiento de Gamboa había intercambiado epístolas (p. 85). En sus profusos y jugosos anexos, el volumen ofrece un glosario de personajes (de gran interés para todo estudioso de las Indias en general); un catálogo de naves de la Armada del Estrecho; un índice de topónimos; una exhaustiva y bien planteada cronología.

En síntesis, esta edición de la Sumaria relación importa porque pone a nuestro alcance y revaloriza un texto central a la hora de pensar narrativas del fracaso en la historia de América. Pero ese es sólo uno de sus logros. En un marco más amplio, esta edición permite repensar problemas de archivo (desperdigado, no editado, intervenido, expoliado); de corpus (¿qué constituye autoría, qué constituye obra, qué lugar ocupan informes, ordenanzas, epístolas?); de canon (¿es posible pensar un canon latinoamericano?) y se coloca, así, en el centro de un diálogo acerca del archivo americano y sus textos fundantes, que ha mostrado un nuevo desarrollo en el Cono Sur en los últimos años. 